10. Попова, И. В. Современный музей: из опыта создания Мемориального музея // Вестник Алтайского государственного педагогического университета. - 2015. - № 24. - С. 132-135.

11. Музей Рождественского Р. И. // КГБУ «Государственный музей истории литературы, искусства и культуры Алтая». - Барнаул, 2013- . - URL: http://gmilika22.ru/category/muzej-rozhdestvenskogo-r-i (11.02.2019).

12. История [Алтайского государственного мемориального] музея [Г. С. Титова] // КГБУ «Алтайский государственный мемориальный музей Г. С. Титова»: [офиц. сайт]. - Косиха, 2012-.- URL: http://www.muzeytitova.ru/about-muzey/history-muzey/ (дата обращения: 26.06.2018).

13. Одинцова, О. В. Всероссийский мемориальный музей-заповедник В. М. Шукшина как культуроформирующий фактор Алтайского региона // Байкальские встречи -VIII: историко-культурное наследие региона как фактор социально-экономического развития региона : матер. междунар. науч.-практ. конф. (Улан-Удэ, 1113 сент. 2014 г.). - Улан-Удэ : Изд.-полиграфический комплекс ФГБОУ ВПО ВСГАКИ, 2014. - С. 446-451.

14. Бийский краеведческий музей им. В. В. Бианки : [сайт]/ МБУ «Бийский краеведческий музей им. В. В. Бианки». - Бийск, 1997- . - URL: http://www.museum.biysk.ru/ru/ (дата обращения: 17.03.2019).

15. Музей истории Алтайской духовной миссии // Бийская епархия Алтайской митрополии Русской Православной Церкви : [сайт]. - Бийск. - URL: http://biyskaya-eparhia.ru/index.php/ru/muzej (дата обращения: 17.03.2019).

Maria $\boldsymbol{V}$. Rygalova, Ph. D. in History Altai State Institute of Culture (Barnaul, Russia) mariya_rygalova@mail.ru

Evgenii V. Rygalov

Altai State University (Barnaul, Russia) rugalov@mail.ru

\title{
HISTORICAL AND CULTURAL POTENTIAL OF ALTAI KRAI (RUSSIA) MUSEUMS IN LOCAL TOURISTIC ROUTES DEVELOPMENT
}

The reported study was funded by Russian Fund of Basic Research according to the research project № 18-39-00112

\begin{abstract}
The article deals with historical and cultural potential of collections kept by memorial and local history museums operated in today's Altai Krai (Siberia, Russia). The authors discuss problems in providing touristic likeability for museums of the region that have rich collections of local history documents and records. Also, the paper analysis perspectives for inclusion of several urban and rural museum institutions into elaborated brand touristic routes, such as Large Golden Ring of Altai and Small Golden Ring of Altai.

Keywords: Large Golden Ring of Altai (touristic route), Small Golden Ring of Altai (touristic route), historical and cultural heritage, museums of Altai Krai, museum collections, tourism, touristic a route.
\end{abstract}

УДК 069.02:39=512.212(571.53)

DOI: 10.32340/2414-9101-2019-4-56-61

В. В. Тихонов, кандидат культурологии

Архитектурно-этнографический музей «Тальиы» (пос. Тальцы Иркутской области, Россия) talci@irk.ru

\section{ОСОБЕННОСТИ СКАНСЕНОЛОГИЧЕСКОЙ ПРАКТИКИ ПО АКТУАЛИЗАЦИИ ИСТОРИКО-КУЛЬТУРНОГО НАСЛЕДИЯ ЭТНИЧЕСКОЙ ГРУППЫ ЭВЕНКОВ В ИРКУТСКОЙ ОБЛАСТИ}

\begin{abstract}
Аннотация. Рассмотрены некоторые вопросы актуализации в Иркутской области (ЮгоВосточная Сибирь, Россия) историко-культурного наследия этнической группы эвенков посредством скансенологической практики. На основе проведённого в регионе детального историкокультурного зонирования выделена эвенкийская историко-культурная зона, для которой определены этномаркирующие составляющие, отличающие этот этнос от других этносов и этнических групп региона. По выделенным этномаркирующим составляющим сформированы экспозиции в региональном Архитектурно-этнографическом музее под открытым небом «Тальцы» (пос. Тальцы Иркутской области, Россия) - осеннее, летнее стойбища и комплекс захоронений, а также экспозиция в Архитектурно-этнографическом музее под открытым небом «Ангарская деревня» (г. Братск Иркутской области, Россия), где сформированы зимнее и летнее стойбища, шаманский комплекс и комплекс захоронений.
\end{abstract}


Ключевые слова: коренные малочисленные народы Сибири, эвенки, этническая группа эвенков, православие у эвенков, шаманизм, стойбище, зимние стойбища эвенков, летние стойбища эвенков, осенние стойбища эвенков, чум, лабаз, охота, оленеводство, воздушное захоронение, погребальный обряд эвенков.

К коренным малым этническим группам в Иркутской области относятся эвенки и тофы. По переписи 1989 года в Сибири проживало 29,9 тыс. эвенков, в том числе этническая группа эвенков в Иркутской области, составлявшая 1046 человек [1, с. 73]. При этом в Иркутской губернии перепись 1897 г. показывала численность эвенков в 2028 человек [2, с. 94]. Такая разница в цифрах объясняется в первую очередь миграцией молодого населения из мест их исконного проживания по всей территории Советского Союза.

Истоки эвенкийского этноса формировались на основе палеоазиатских племён в V-VI веках н.э., таких как кеты, курыканы, юкагары. Постепенно образовалось два ореола эвенкийской культуры на территории Иркутской области: западный и восточный (забайкальский, витимский), условная граница между ореолами проходила по оз. Байкал [3, с. 51]. Первоначально протоэвенки расселялись по таёжной территории и даже освоили территорию приполярной тундры $[4$, c. 10]. При этом продвижение протоэвенкийского этноса на территорию Подкаменной и Нижней Тунгусок сопровождалось ассимиляцией местных племён кетов, ненцев, наганасан, а впоследствии, в XVII - XVIII вв., многие группы предбайкальских эвенков слились с бурятскими родами. В средние века шло вытеснение эвенков с южных территорий Иркутской области бурятами и, в последующем, русскими на север. При этом буряты и эвенки ассимилировались или роднились, последние переходили в бурятский этнос, что обосновывалось экономически, так как ясак русскими взимался неравномерно [5, с. 149]: с бурят ясака брали в пять раз меньше, чем с эвенков [6, с. 39]. Временем окончательного оформления ясачной повинности у самых северных тунгусских эвенков считают 1634 г. [4, с. 25]. Обременение касалось только эвенков мужского пола в возрасте от 16 до 50 лет [4, с. 47]. Западный и восточный ореолы разделялись территориями и использованием эвенками оленей. Западные эвенки оленей использовали как вьючное животное, восточные (орочены) как ездовое животное [7, с. 80].

Основная направленность жизненного уклада эвенков - это охота и оленеводство. При этом охота велась в основном на пушного зверя, в первую очередь на соболя и белку. Вспомогательную роль играли нетоварное рыболовство и сбор дикоросов, в основном, кедрового ореха [8, с. 16]. Эвенки, проживавшие вдоль побережья оз. Байкал, также не занимались товарным рыболовством. Принадлежащие им родовые тони они сдавали в аренду русским промысловым бригадам, взамен получали ренту в денежном эквиваленте, на которую покупали продукты и различные товары [9, с. 98]. Ведя в основном кочевой образ жизни, одна или несколько семей эвенков на протяжении многих лет осваивали определённую хозяйственную территорию, охватывающую охотничьи, рыболовные и пастбищные угодья [7, с. 124]. Средняя численность одной семьи составляла обычно 5 человек [7, с. 40]. К началу XX века многие эвенкийские семьи перешли на полукочевой образ ведения хозяйства. Появились стойбища в виде деревень, как, например, в Верхоленском округе, где в деревню объединялись от 6 до 13 семей [6, с. 20]. Основным товарным промыслом эвенков была добыча пушнины, и за каждой эвенкийской семьей были формально закреплены охотничьи угодья, площадь которых примерно равнялась 75 тыс. га [7, с. 41], или размером 10х75 км. При передвижении в летний сезон семья могла проходить до 150-200 км, при дневном маршруте в 15 км [7, с. 47]. На территориях, осваиваемых эвенкийской семьёй, организовывались стоянки (стойбища) в зависимости от сезона: зимние, весенние, летние и осенние. Зимние стойбища осваивались [7, с. 134] с начала выпадения снега и до середины февраля, когда утрамбованный снег-наст позволял заниматься охотой. Тогда охотники небольшими группами, иногда поодиночке, уходили на охоту на 2-3 недели, передвигаясь по 10 км в день, иногда останавливаясь на непродолжительных стоянках сроком на 2-3 дня. Для зимнего стойбища выбирали сосновый лес у реки. Комплекс зимнего эвенкийского стойбища мэнзйен в основном состоял из голомо (корьевого чума), продуктового настила - лабаза, изгороди вокруг чумов, пасти (ловушки для пушных зверей) [9, с. 332]. Чум голомо строили из расколотых повдоль брёвен и укладывали вертикально в виде конуса, оставляя вверху отверстие для выхода дыма. Чум в пазах полубрёвен утеплялся мхом и покрывался лиственничной корой. Вход в чум закрывали родвужной шкурой. В центре размещался очаг, сформированный брёвнами, для сидения уложенными П-образно открытой стороной к выходу. На высоте 1,2-1,5 м от земли, над очагом, параллельно земле закреплялись одна или две жерди для подвешивания котелка или чайника. Вдоль стен укладывали хвойный (сосны, пихты) лапник, таким образом организуя спальные места. Напротив входа у православных эвенков на стене закреплялась икона Николая Чудотворца. Вообще считается, что к XIX в. эвенки по большей 
части стали двоеверцами (православными шаманистами). Так, по данным на 1884 г. в Приангарье насчитывалось только 366 некрещёных эвенков [6, с. 51]. Лабаз - настил в зимнем стойбище - служил для хранения несезонных вещей в период перекочёвок. Продуктовый лабаз представлял собой маленький сруб с крышей, располагавшейся на высоте 3,5-4,5 м над землёй, и использовался для хранения съестных припасов. Такая конструкция лабаза позволяла уберечь припасы от диких животных. Изгородь вокруг чумов ставилась в 15 м от них по окружности, чтобы олени не добрались до коры на чумах. Пасть ланг использовали в основном после перекочёвки семьи и собак на весеннее или летнее стойбища [10, с. 60]. После ухода людей дикие животные (росомахи, лисицы, песцы, волки) стремились поживиться в пустующем стойбище и попадали в примитивные ловушки-пасти на наживку в виде мяса.

С конца апреля по сентябрь эвенки жили на летних стойбищах дюверкит. Часто эти стоянки были кратковременными, так как все решало качество пастбища для оленей. Олень и собака были основными животными у эвенков. Олень давал мясо и шкуру, использовался как вьючное и ездовое животное. Собака охраняла человека и помогала на охоте. B XV-XVIII вв., когда пушной промысел становится товарным производством у эвенков, основное поголовье оленей, вполне достаточное для обеспечения семьи и кочевого образа жизни, составляло 5-10 оленей на семью. В XIX - начале ХХ вв. средняя эвенкийская семья располагала 25-30 головами оленей [7, с. 85]. В летне-осенний период основными продуктами питания у эвенков были мясо и рыба. Ближе к осени делали заготовки на зиму. Рыбу ловили в реках сетями, корчагами, мордами, вертами. Для ночной ловли использовали берестяной факел и острогу. Ставили загородку укикит на небольших речушках, где скапливалась рыба, когда шла на нерест.

Для жилья на летних стойбищах эвенки ставили чумы ровдужные и лёгкие берестяные [7, c. 148]. Ставились они на продуваемых ветром территориях вблизи рек. Сооружали переносные чумы эвенки быстро, за 1,5-2 часа. Если место ранее было освоено под стоянку, то каркас чума уже был готов в виде конусообразно стоящих жердей. Высота чума варьировалась от дымохода в пределах от 2,5 до 4 м, в диаметре размеры были такими же. Чум покрывался ровдугой, специально выделанными шкурами сохатых, сшитыми в полоски. Начиналась укладка снизу и далее вверх по заранее сформированной схеме. Ровдужные полосы вставлялись один в зацеп другой и так доверху. Чтобы шкуры не сдувало сильным ветром, их снаружи прижимали жердями и закрепляли вверху чума изготовленным из тальника ободом. На чум уходило от 15 до 22 лосиных шкур [11, с. 15]. Установка берестяного чума занимала столько же времени, как и ровдужного. Технология сборки практически ничем не отличалась. Только вместо ровдужных лент использовали берестяные. Автор встречал и совсем маленькие берестяные чумы диаметром и высотой в 1,2 м. Однако такие чумы делались очень редко. Вторым главным сооружением летнего стойбища были дымокуры. Гнус - это очень серьёзная проблема в тайге, в особенности для оленей. И только дым разгоняет гнус. Дымокуры по размерам были от 1 до 3 м в высоту. Сооружались по одному принципу в виде установки жердей на конус, как каркас чума. Особенностью дымокура была плотность жердей, исключающих приближение оленей к тлеющему костру. В большом дымокуре для дыма использовали трухлявые бревна, а в маленьком - трухлявые ветки и мох. Неотъемлемой частью любого эвенкийского стойбища был костёр гулувун [11, с. 60]. Его сооружали перед чумом для приготовления пищи. Состоял он из двух вертикальных, на конце рогатых, палок, воткнутых в землю, и перекладины для подвешивания котелков и чайников. Сбоку от чумов сооружали из уложенных по земле жердей место для сёдел и потакуев. Учитывая, что в летнее время ловили рыбу, на стойбище было приспособление для сушки и ремонта сетей [11, с. 61], состоящее из двух оснований в виде треноги из жердей, и поперечно закреплённой на эти треноги жерди, на которую и навешивали сеть. Высота сушила для сетей была от 1,5 до 2,0 м. Отдельно, с использованием двух деревьев, и уложенной на вбитых в них спицах перекладине сооружали, с использованием отвеса, приспособления для снятия жира со шкур и сушки кожи. Ровдугу изготавливали с помощью мялки, сделанной по русскому образцу, которая в обязательном порядке имелась на стойбище. Ровдугу изготавливали исключительно из шкур лося или сохатого, погружая её на 2-3 недели в воду, потом снимая с размокшей шкуры волосяной покров, обсушивали в дыму над костром, чтобы предотвратить появление паразитов. На завершающем этапе использовали мялку для придания эластичности. Таким же образом готовили шкуры оленей для одежды, обуви, одеял, исключая из процесса обработку дымом. На летних стойбищах для изготовления элементарных предметов быта из металла сооружали кузни, состоящих из горна, где разводился костёр, из шкур и досок делали примитивные меха. Над горном возводился навес на случай дождя, который покрывался лиственничной корой. Рядом с горном ставилась чурка, в которую вбивали металлическую бабку - наковальню, наподобие той, которую русские использовали для отбивки кос. При отсутствии металлической 
бабки в качестве наковальни использовали валуны. Для хранения некоторых вещей сооружали навесы (дэлкэны). Чаще всего их делали в виде помоста на рядом стоящих четырёх или трёх срубленных деревьях. Вещи укладывали на помост, закрывали сверху закреплёнными к помосту шкурами. Высота дэлкэна для вещей обычно была около 2 м. Так вещи хранились до следующего прихода на эту стоянку. Летние стойбища в целях восстановления травяного покрова посещались через 4-5 лет [7, с. 137]. Для рыбалки и передвижения по рекам эвенки использовали долблёные и берестяные лодки. Для изготовления долблёной лодки требовалось довольно много времени. Поэтому их обычно делали и хранили под специальным навесом, покрытым в верхней части лиственничной корой. На летних стойбищах в основном использовали лодки берестянки. Автор был свидетелем, как такую лодку эвенк изготавливал за один день. Из веток черёмухи делался каркас и обтягивался сшитыми листами бересты. Пазы в бересте заделывались смолой хвойных деревьев. Такие лодки были очень лёгкими, их перевозили с собой или просто бросали при длительных перекочёвках.

Весенние и осенние стойбища по набору сооружений практически не отличались. Основным объектом таких стойбищ был корьевой чум (голомо) без дополнительного утепления мхом. О покрытии чумов в разных источниках даётся информация, что листы лиственничной коры укладывались на жерди как повдоль, так и поперёк структуры листа. Есть даже информация, что покрытие делалось рядами косо уложенных листов [7, с. 152]. Автор, правда, последнего способа в экспедициях не наблюдал. В составе осенних стойбищ были лабазы. Это небольшие клети под крышей, стоящие на одном, двух или четырёх столбах высотой 2,5-4 м, где хранились съестные припасы. Дэлкэны для хранения сезонных вещей $[11$, с. 60]. Ланг-капкан на пушного зверя $[11$, с. 61]. Навес для лодки долблёнки. Кострище для приготовления пищи. Место для седел и потакуев. Для вяления мяса использовались плетёные решётки из тальниковых прутьев, подвешиваемые на вбитые в землю колья [7, с. 150]. Под решёткой разводился дымокур. Интересным сооружением весенних и летних стойбищ был дэлкэн для хранения костей съеденных животных. Кости по стойбищу не разбрасывались, а укладывались на помост, чтобы олени не могли их достать. Это связано с тем, что у оленей слабая челюстная мускулатура, значительно более слабая, чем у собак, и большой костью олень мог подавиться. После того, как в 30-х годах XX века эвенков стали сгонять в колхозы, в одном месте скапливалось большое количество оленей, в результате они заболевали так называемой «копыткой», связанной с недостатком кальция в организме. Поэтому кости хранили до трухлявости, долбили их и потом скармливали оленям. Вокруг осеннего стойбища эвенки сооружали изгородь, для так называемого «осеннего огорода», с проходами в виде заострённых жердей. Это позволяло оленям внутрь стойбища заходить свободно, а обратному выходу препятствовали острые жерди [7, с. 152]. По тропе, уходящей со стойбища, ставили деревянного идола Хэвеки [9, с. 192].

C середины XX века эвенки постепенно стали переходить на полуоседлый образ жизни. На стойбищах, в основном зимних, стали появляться дома-клети по-русски с глинобитной печью [6, с. 21]. Очеульские эвенки уже в 1845 году имели по 35 лошадей и 9 коров, а в 1864 году - соответственно по 127 и 33 [8, с. 14]. По статистике на 1926 год эвенки-орочены проживающие в устье реки Хомолхо в 32 хозяйствах располагали 65 лошадьми и 17 коровами [12, с. 629]. Несмотря на оседлость некоторой части эвенков в Иркутской области в первой четверти XX века, основная масса их вела кочевой образ жизни, продолжая разводить оленей и заниматься охотой. Охотились на зверя как для пропитания, так и в качестве товарного промысла, в основном на соболя и белку. Практически вся охота на соболя и белку велась с помощью различного рода приспособлений (капканов) - кулемки, плашки, обметины, сети и т. д. [11, с. 25-26].

Уникальной составляющей духовной культуры эвенков является погребальный обряд. Для похорон умершего на возвышенности выбирали два дерева ориентиром с востока на запад. В деревянной колоде, расколотой пополам, выдалбливали полость для покойника. Срубались деревья на высоте 3-4 м, и на них с помощью определённых приспособлений устанавливался гроб с покойником. Иногда гроб делали из колотых плах. Постепенно к концу XIX века эвенки для захоронений стали использовать наземный способ. Покойник укладывался на землю, покрывался мхом, и над ним делали из брёвен гобец высотой около 1,2 м. Такой гобец не позволял диким животным осквернить труп. В начале $\mathrm{XX}$ века уже встречаются наземные захоронения в виде сплошного дощатого гобца с установкой креста на макушке. При захоронении эвенка в гроб клали продырявленную посуду, трубку, табак, обувь и т. д. [11, с. 22]. Укладывали умершего в гробу головой на запад.

Итогом данной работы стало выделение этномаркирующих составляющих этнической группы эвенков, отличающих их от других этносов и этнических групп, проживающих на территории Иркутской области. Это позволило приступить к формированию экспозиционного пространства регионального этнографического музейного комплекса под открытым небом «Тальцы» (г. Иркутск), где экспо- 
зиционным методом проведена актуализация историко-культурного потенциала эвенкийского этноса музеефицируемой территории. За основу формирования отдельных экспозиций были взяты сезонные (осенние, летние) стойбища-стоянки эвенков, а также комплекс захоронений. Зимнее стойбище и эвенкийская деревня-стойбище с домами по русскому образцу в разработку пока не брались. Осеннее эвенкийское стойбище сформировано в аналогичных ландшафтных условиях (лесу) и включает в себя корьевой чум-голомо, лабаз для продуктов на четырёх столбах, место для седел и потакуев, кожемялку без навеса, дэлкэн для вещей, пасть-ланг, навес для лодки долбленки вместе с лодкой, дэлкэн для костей, приспособление для вяления мяса - бусивун [9, с. 199]. На выходе из стойбища установлен деревянный идол Хэвеки. Стойбище огорожено жердевой изгородью, сделанной без единого гвоздя. В изгороди сформированы проходы для оленей - хоннго.

В основу летнего эвенкийского стойбища заложены естественный природный ландшафт, а также типичные сооружения: каркас для ровдужного чума, дымокуры, кострище для приготовления пищи, сушила для сетей, приспособление для обезжиривания шкур, кузница [10, с. 60]. Третьим объектом эвенкийской экспозиции в Архитектурно-этнографическом музее «Тальцы» стал комплекс эвенкийских захоронений, состоящий из воздушных захоронений на столбах и двух наземных погребений: в первом случае - из бревенчатого сруба, во втором - из дощатого гобца с крестом. В перспективе в музее планируется воссоздание стоянки чума шамана, в основе которой будет небольшой чум с берестяным покрытием и всей остальной атрибутикой шаманской жизни. Эвенкийскую экспозицию в музее воссоздавал эвенк Удыгер Иосиф Трофимович, который свои молодые годы провёл в аналогичных стойбищах. Ещё одним музейным комплексом, отражающим традиционную культуру эвенков Подкаменной Тунгуски стал Архитектурно-этнографический музей «Ангарская деревня» (г. Братск) $[13$, c. 37-38]. Эвенкийская экспозиция показана в музее за счёт примерного воссоздания летней стоянки, зимнего стойбища, шаманского комплекса и показа двух типов захоронений: воздушного и подземного, а также отдельно стоящих объектов в виде разнотипных лабазов [14, с. 33-36]. Строительством экспозиции занимались Г. С. Уткин и А. А. Павлов. Основу зимнего стойбища составляют ровдужный чум, корьевой чум, крытый лиственничной корой (голомо) и балаган по якутскому образцу. В стойбище воссозданы лабаз на четырёх опорах для хранения имущества и лабаз на одной опоре для хранения продуктов. В летнем стойбище - два чума, крытых берестой, кузница, мялка для выделки шкур и кожи, дымокур, кострище и загон для оленей. Между стойбищами установлены образцы лабазов и дэлкэн для хранения продуктов и имущества. Шаманский комплекс представлен корьевым летним чумом и шаманской атрибутикой, изображающей духов в виде антропоморфных и зооморфных фигур рыб и птиц [13, с. 35]. Комплекс захоронений показан через воздушные и подземные захоронения. Воздушное захоронение сооружено из колотых плах.

Развитие темы историко-культурного наследия эвенкийского этноса в Иркутской области видится в проектируемой в пос. Ключи Казачинско-Ленского района эвенкийской экспозиции в этнографическом музее под открытым небом «Ленская деревня» [15, с. 20-21]. По аналогу с музеем «Тальцы» планируется создать осенние, летние стойбища и комплекс захоронений, разнообразя экспозицию отличными от музея «Тальцы» объектами. Вне Иркутской области в Республике Бурятия в этнографическом музее народов Забайкалья «Верхняя Березовка» также сформирована экспозиция по шаманизму эвенков Прибайкалья в виде шаманского комплекса, состоящего из корьевого чума и шаманской атрибутики, в принципе, аналогичной такому же комплексу в братском музее «Ангарская деревня» [16, с. 25]. Учитывая то, что наше поколение ещё было свидетелем патриархальной культуры эвенкийского этноса, фиксация этого историко-культурного наследия в наше время в виде музейных экспозиций позволяет передать истинные элементы культуры эвенков будущим поколениям в наименее искажённом виде.

\section{Список литературы}

1. Тихонов, В. В. К вопросу о строительстве эвенкийского стойбища в музее «Тальцы» // Известия Архитектурно-этнографического музея «Тальцы». - 2002. - № 1. - С. 173.

2. Тихонов, В. В. Отличительные моменты материального наследия этносов и этнических групп, сформировавших историко-культурный потенциал Предбайкалья второй половины XIX - начала XX века // Вестник Кемеровского государственного университета культуры и искусств. - 2013. - № 23. - С. 93-100.

3. Тихонов, В. В. Музей - один из вариантов сохранения культурной и духовной культуры малочисленных народностей // Словцовские чтения-1995 : сб. тез. науч.-практ. конф. (Тюмень, 16-17 ноября 1995 г.) Тюмень : ИПП «Тюмень», 1995. - С. 50-52.

4. Туров, М. Г. Этническая и социальная история Катангского района Иркутской области / М. Г. Туров, В. И. Литвина, В. Г. Ступин. - Иркутск : Изд-во Иркутского государственного университета, 1995. - 165 с. 
5. Туголоуков, В. А. Межэтнические связи и культуры Приангарских эвенков в XVII-XVIII вв. // Проблемы этногенеза и этнической истории аборигенов Сибири : сб. науч. тр. - Кемерово : КГУ, $1986 .-$ C. $148-159$.

6. Туголуков, В. А. Тунгусы (эвенки и эвены) Средней и Западной Сибири. - Москва : Сибирские промыслы, 1985. - 284 с.

7. Туров, М. Г. Хозяйство эвенков таежной зоны Средней Сибири в конце ХIX-начала ХХ века (Принципы освоения угодий). - Иркутск : Изд-во Иркутского ун-та, 1990. - 176 с.

8. Туголуков, В.А. Изменения в хозяйстве и быте эвенков Иркутской области за полтора века // Советская этнография. - 1965. - № 3. - С. 12-26.

9. Тихонов, В. В. Историко-культурное наследие Предбайкалья и перспектива его сохранения методом этнографических музейных комплексов под открытым небом.-Иркутск: Изд-во ООО «Репроцентр А1», 2013. - 364 c.

10. Тихонов, В. В. Эвенкийское стойбище музея «Тальцы» // Известия Архитектурно-этнографического музея «Тальцы». - 1998. - № 2. - С. 59-62. 66.

11. Самохин, А. Т. Тунгусы Бодайбинского района // Сибирская живая старина. - 1929. - Вып. 8/9. - С. 5-

12. Тихонов, В. В. Этническая карта Предбайкалья во второй половине XIX - первой четверти XX века // Седьмые всероссийские краеведческие чтения (Москва-Омск, 13-17 мая 2013 г.). - Москва : ИЦ «Краеведение», 2013. - С. 628-636.

13. Шевченина, Л. А. «Ангарская деревня» / Л. А. Шевченина, В. М. Семёнов // Известия Архитектурноэтнографического музея «Тальцы». - 1997. - № 1. - С. 33-39.

14. Павлов, А. А. Экспозиция эвенкийского сектора музея «Ангарская деревня» // Известия Архитектурноэтнографического музея «Тальцы». - 1996. - № 11. - С. 33-38.

15. Тихонов, В. В. Этнографический музей под открытым небом «Ленская деревня» в посёлке Ключи Казачинско-Ленском районе Иркутской области / В. В. Тихонов, А. К. Нефедьева. - Иркутск : Изд-во ООО «Репроцентр А1», 2007. - 24 с.

16. Цыдыпова, Р. И. Этнографический музей народов Забайкалья // Известия Архитектурноэтнографического музея «Тальцы». -1996. - № 1. - С. 24-27.

Vladimir V. Tikhonov, Ph. D. in Cultural Studies Architectural and Ethnographic Museum «Talzy» (Talzy village, Irkutsk Oblast', Russia) talci@irk.ru

\section{SCANSENOLOGICAL PRACTICE IN ACTUALIZATION OF EVENKS' HISTORICAL AND CULTURAL HERITAGE IN IRKUTSK OBLAST' (RUSSIA)}

Abstract. The paper discusses issues of actualization of Evenks' historical and cultural through scansenological practice in Irkutsk Oblast' (southeastern Siberia, Russia). Detailed historical and cultural zoning let to uncover Evenks' historical and cultural zone, it got its ethnic marks that helped to distinguish this ethnos from other ethnic groups and communities settle the region. These ethnic marks were taken as a basis of such exhibitions in regional Architectural and Ethnographic Museum «Talzy» (Talzy village, Irkutsk Oblast', Russia) as autumn and summer camping grounds, burial complexes, as well as exhibition in Architectural and Ethnographic Open-Air Museum «Angara village» (Bratsk, Irkutsk Oblast', Russia) that shows winter and summer camping grounds, shamans' complex and group of burial places.

Keywords: indigenous minority of Siberia, Evenks, ethnic community of Evenks, Eastern Orthodox Christianity, shamanism, nomad camp, Evenks' winter camping ground, Evenks' summer camping ground, Evenks' autumn camping ground, raw-hide tent, cache, hunting, reindeer breeding, air burial, Evenks' funeral ritual. 